\title{
IMPACT OF BRAND EQUITY ON PURCHASE INTENTIONS BUYING FOOD PRODUCTS IN LITHUANIA
}

\author{
Asta Kyguoliene ${ }^{1}$, Kristina Zikiene $e^{2}$ \\ ${ }^{1}$ Assoc. prof., PhD., Vytautas Magnus University, K. Donelaicio st. 58, LT-44248, Kaunas, Lithuania. \\ E-mail address: asta.kyguoliene@vdu.lt \\ ${ }^{2}$ Assoc. prof., PhD., Vytautas Magnus University, K. Donelaicio st. 58, LT-44248, Kaunas, Lithuania. \\ E-mail address: kristina.zikiene@vdu.lt
}

Received 2308 2021; Accepted 30082021

\begin{abstract}
Increasing significance of brand equity encourages to analyse brand equity concept, its dimensions, and their impact on purchase intentions. Understanding why customers are willing to purchase certain food brands can help both retailers, and food product's manufacturers build brands and compete in the market. Thus, the aim of this research is to evaluate the impact of brand equity dimensions on purchase intentions buying food products in Lithuania. Research methods: literature analysis, comparative, systematic analysis, questionnaire survey as a quantitative method, data analysis, regression analysis was used to achieve the aim. Results indicate that brand awareness doesn't have significant impact on purchase intentions buying food products in Lithuania. Brand image, perceived quality and brand trust are deeply associated with purchase intentions buying food products in Lithuania and influence purchase intentions in a given order by their impact.
\end{abstract}

Keywords: brand awareness, brand equity, brand equity dimensions, brand image, brand trust, perceived quality, purchase intentions.

JEL codes: M31, M11, Q02, L66.

\section{Introduction}

In last decades interest in brand equity increased significantly. Nowadays, brand equity is considered as key business strategic asset of a company (Vukasovic, 2016), strategic question of building competitive advantage (Moradi, Zarei, 2011), an important part of brand building (Pappu et al, 2005), a metric for evaluating long term marketing decision impact (Atilgan et al, 2005). The concept of brand equity is multidimensional, analysed from various perspectives. Consumer-based approach considers brand equity as an added value generated by the brand. Brand equity construct consists of different dimensions. The range of dimensions of brand equity evolved from Aaker
(1991) four dimensions: brand awareness, brand association, perceived quality, brand loyalty to many more defined by different scholars: brand image, brand trust, personality, attitude, attachment, satisfaction, esteem, etc. Scholars discuss that brand equity dimensions impact purchase intensions. Some state that brand equity first impacts brand preference and then purchase intentions (Chang and Liu, 2009), others declare that brand equity dimensions can impact purchase intentions directly (Moradi and Zarei (2011). It is not under discussion, that dimensions make impact. More it is about what impact makes different dimensions.

Copyright (C) 2021 Author(s), published by Vytautas Magnus University. This is an open access article distributed under the terms of the Creative Commons Attribution Non-Commercial 4.0 (CC BY-NC 4.0) license, which permits unrestricted use, distribution, and reproduction in any medium provided the original author and source are credited. The material cannot be used for commercial purposes. 
Jalilvand et al (2011) state that the number of studies which aim to measure the effect of brand equity dimensions on purchase intensions is limited. Thus, research problem is formulated as a question: what impact has brand equity dimensions on purchase intentions?

The objective of this research is the impact of brand equity dimensions on purchase intentions.

Purchase intensions are at a core interest of each retailer and manufacturer because customer decisions become more complex, products are very standardized, supply exceeds demand (Baalbaki and Guzman, 2016). This tendency is extremely significant buying food products. Anselmsson et al (2007) indicate that development of a brand equity framework for grocery products contributes to a better understanding of why consumers are willing to purchase certain brands. Grocery retailing in each country plays a major role. According to Deloitte (2021), analysing 2019 fiscal year of Top250 retail companies in the world, FMCG sector accounts for 66 percent of a market share of Top250 retail companies. This explains the importance of whole FMCG sector, which mostly includes food. Thus, customers' purchase intentions to buy food is significant for food market. Based on this significance it is worth to analyse brand equity dimensions impact on purchase intentions buying food products.

The aim of this research is to evaluate the impact of brand equity dimensions on purchase intentions buying food products in Lithuania.

Research methods: literature analysis, comparative, systematic analysis was used to study the scientific problem. Questionnaire survey of the respondents as a quantitative method, data analysis was used for empirical research. Regression analysis made to achieve the aim.

Benefit of the research: the research results provide answer what impact analysed brand equity dimensions make on purchase intentions buying food products in Lithuania. This knowledge can be applied in practice building brands of food products.

\section{Literature review on brand equity and its impact on purchase intentions}

Brand equity concept and term has been discussed by various scholars. Though, the original definition of brand equity defines it as added value with which a given brand endows a product (Farquhar, 1989), the concept can be discussed from different perspectives (Moradi, Zarei, 2011; Boo et al, 2009; Baalbaki, Guzman, 2016). Financial and monetary value of brand in market is the first approach to evaluate brand equity. The second one - consumer-based brand equity. It covers added value of product or service which appears by awareness of consumers and brand perceptions. The third one is the mix of financial and consumer-based approaches (Moradi, Zarei, 2011). Following Baalbaki and Guzman (2016), several perspectives for brand equity analysis can be discussed: cognitive psychology perspective how customers respond to a brand's marketing mix given, what customer perceive and associate with a brand; information economics perspective - the increased utility that a brand name gives to a product; financial markets perspective. Employee-based brand equity perspective was proposed by Kind and Grace (2009), analysing the effect of brand knowledge to employees' response to their work environment. In this article brand equity is analysed from one, i.e., the consumer-based approach. Consumer-based approach concentrate on the knowledge of consumers about the brand and covers a wide range of aspects. According to Shariq (2018), brand equity under this approach can be understood as the value generated by a brand, by virtue of its name, the associations and emotional connect that the consumer has in mind. Moradi, Zarei (2011) state that brand equity depends on consumers' experiences, feelings and what they learn about the brand in a long term. Following Leone et al. (2006), the term brand equity is described as the added value that connects to the product in consumers mind, words, and actions. It can be summarized that 


\section{sciendo}

\section{Management Theory and Studies for Rural Business and Infrastructure Development \\ eISSN 2345-0355. 2021. Vol. 43. No. 3: 373-382 \\ Article DOI: https://doi.org/10.15544/mts.2021.34}

brand equity acts as a link between customers and brands.

Brand equity can be conceptualized analysing its' dimensions. The operationalization of consumer-based brand equity can be divided into consumer perceptional and behavioural dimensions (Chen and Chang, 2008; Seric and Gil-Saura, 2020; Hazee et al., 2017). Brand awareness, brand association, perceived quality is understood as perceptional dimensions and brand loyalty as behavioural. According to Aakers (1996), brand equity can be conceptualized by brand loyalty, brand name awareness, perceived brand quality, brand associations, and other proprietary brand assets. Keller (1996) states, the brand equity cannot be analysed without including a dimension of the brand image, which has close associations with the brand itself. Brand trust, as one of dimensions of brand equity, is widely mentioned in academic literature too (Shariq, 2018; Delgado-Ballester and Munuera-Alema'n, 2005), considering it at the core of brand equity, because it is a key characteristic of any successful long-term relationship (DelgadoBallester and Munuera-Alema'n, 2005). Shariq (2018) identifies 11 brand equity dimensions: quality, associations, awareness, loyalty, image, trust, personality, attitude, satisfaction, esteem, attachment. Despite the variety of dimensions that define brand's equity, later in the article perceived quality, brand awareness, brand image and brand trust are analysed, as the one on which the empirical research in based.

Perceived quality. According to Aaker (1996), perceived quality is one of the key elements that characterize brand equity. Perceptions about the products, intangible quality, overall feeling about the brand is the key analysing perceived quality, but not technical quality, though it is based on key dimensions, features of the products to which the brand is attached such as reliability and performance (Shariq, 2018). Perceived quality usually is regarded as overall assessment and can affect brand image (Alhaddad, 2015). As a key driver of brand's equity perceived quality can play a major role determining consumer's choice (Severi and Choon Ling, 2013) and has a positive relation on purchase intensions. High perceived quality provides customers a reason to buy (Jalilvand et al, 2011), convinces customers to buy the brand, helps to differentiate, allows to increase a price, extent the brand (Aaker, 1991), enhance brand loyalty (Buil, 2013). Perera et al. (2019), Dissabandara (2020) agree that perceived quality influence purchase intentions and is directly linked with them.

Brand awareness. Brand awareness is defined as the ability of a potential buyer to recognize or recall that a brand is a member of a certain product category (Shariq, 2018). Baalbaki and Guzman (2016) state that brand awareness is the first step in building brand equity. According to Jalilvand et al (2011), if the consumer has a high level of awareness and familiarity with the brand and holds some strong, favourable, and unique brand associations in memory, brand equity increases. The range of brand awareness can be wide: from uncertain feelings that the brand is recognized to a belief that it is the only choice in the category (Shariq, 2018). The depth and breadth of brand's awareness determine brand equity (Shekhar Kumar et al, 2013). According to Civelek, Ertemelb (2019), brand awareness is the ability of a brand to get recognized before customers make purchase intentions. Brand awareness influence the formation and the strength of a brand associations, including perceived quality (Buil, 2013), effects the decision making of a consumer about a product, because when customer considers buying something, he considers a brand. According to Jalilvand et al (2011), brand awareness plays an important role in consumer decision making process because of learning, consideration, and choice advantages, together with the brand image creating 
additional value to the firm and customers. Relationship between brand awareness and purchase intentions are confirmed by different scholars. Tariq et al (2017) agree that brand awareness has strong relationship with purchase intentions, as well as Akhtar et al. (2016), Noorlitaria et al (2020) confirms this close linkage.

Brand image. If brand awareness is about ability to link the product to a category, brand image is about individual associations with a brand. According to Zhang (2015), brand image is the key driver of brand equity, which refers to consumer's general perception and feeling about a brand. Following the definitions, brand image is understood a set of associations, usually organized in some meaningful way (Aaker, 1992), as perceptions about a brand reflected by the brand associations held in consumer memory (Shariq, 2018). Strong, unique, favourable associations with a brand lead to stronger brand image (Baalbaki and Guzman, 2016). Nevertheless, it is impossible totally to control brand image because it is on receiver's side, just some associations can be partially controlled by marketing mix, other associations depend on external issues (Baalbaki and Guzman, 2016). Graeff (1997) state that a consumer purchase decision most often depends on brand image rather than physical characteristics of brand.

Brand trust. According to (Shariq, 2018), brand trust is part of the brand/consumer relationship and therefore brand equity. Brand trust forms an emotional memory and is linked to the individuals' expectations what safety and brand's purposes are concerned, especially in situations of risk for the consumer (Ballester, 2002). Building brand trust is a long-term process, related to customer's experience. Strong to build, easy to destroy - this well describes brand trust. Lyubenova (2019) state that the main attributes of brand trust are consistency, honesty, and concern. Building these attributes brand can capture customers' assurance. Brand trust is often described as a predictor of repetitive purchase behaviour and a moderator of the impact of brand loyalty (Ballester, Munuera-Alem, 2005).

Different scholars argue about brand equity power and effect on purchase intentions, empirical evidence indicates that brand equity can affect purchase intentions in different contexts (Jalilvand et al, 2011). According to Cobb-Walgren et al. (1995), brand equity influence brand preference and purchase intentions directly and ultimately influence consumers' brand choice. If brand equity leads to brand preference, brand preference reflects in purchase or usage intentions (Chang and Liu, 2009). Following Moradi and Zarei (2011), both brand preferences and purchase intentions are consequences of brand equity. Brand equity can be considered as independent variable, brand preference and purchase intentions - as dependent variables. As well authors state, that purchase intentions can follow as well from brand preference or directly from brand equity, i.e., purchase intentions can be considered as directly impacted by brand equity and its dimensions. Thus, summarizing literature review, it can be stated, that consumers' purchase intentions are related with brand awareness, brand image, perceived quality, and brand trust. Brand equity and purchase intentions relationship framework is presented in Figure 1. 


\section{sciendo}

Management Theory and Studies for Rural Business and Infrastructure Development eISSN 2345-0355. 2021. Vol. 43. No. 3: 373-382

Article DOI: https://doi.org/10.15544/mts.2021.34

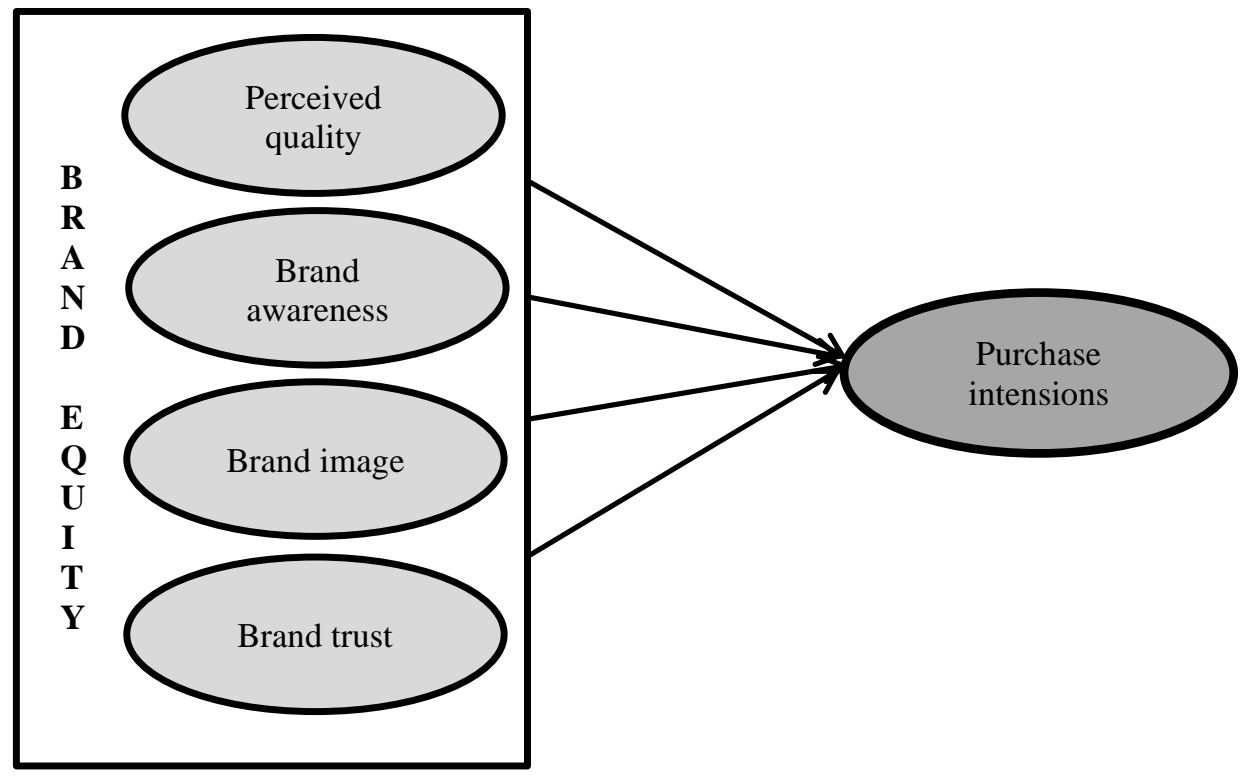

Figure 1. Brand equity and purchase intentions relationship framework

Following the framework, provided in Figure 1, it is worth to consider not only relationship, but what impact makes each brand equity dimension on customers' purchase intention. This could help to understand customers' choice and provide practical recommendations what to focus on.

\section{Research methodology}

Determining the impact of brand equity on customer purchase intentions, the questionnaire research was prepared. The questionnaire was based on the following steps: firstly, the brand equity and its impact on customers' purchase intentions was measured; second, the demographics of the respondents were collected.

Measurement model. Anselmsson et al (2007) indicate that development of a brand equity framework for consumer-packaged food contributes to a better understanding of why consumers are willing to purchase certain brands. Thus, a quantitative study, based on theoretical brand equity and purchase intentions relationship framework, was performed investigating the impact of brand equity dimensions on purchase intentions buying food products in Lithuania. To determine this impact, 18 questions were prepared.
The first question was composed to ascertain whether the respondents were aware of the Lithuanian food product brands presented, which later were used in the survey questions to evaluate the impact of brand equity dimensions on purchase intensions.

The following questions in the questionnaire were designed to determine and evaluate the dimensions of brand equity and their impact on purchase intentions.

Each dimension of brand equity perceived quality, brand awareness, brand image and brand trust were converted into specific statements, directly associated with Lithuanian food products 'brand. Perceived quality, as a dimension of brand equity, was converted into 3 specific statements, brand awareness was converted into 2 specific statements, brand image was converted into 4 specific statements and brand trust was converted into 3 specific 
statements. Purchase intentions, as the result of the impact of brand equity dimensions, was converted into 2 specific statements. The measurement statements for all dimensions are presented in Table 1.

\section{Table 1. Measurement Statements for Brand Equity Dimensions}

\begin{tabular}{|c|c|}
\hline Brand equity dimensions & Measurement statements \\
\hline \multirow{3}{*}{$\begin{array}{l}\text { Perceived quality } \\
\text { (Shariq, 2018; Alhaddad, 2015; Severi and Choon Ling, } \\
\text { 2013; Perera et al., 2019; Dissabandara, 2020) }\end{array}$} & Overall, I rate X brand products very well \\
\hline & $\begin{array}{l}\text { The quality of X brand products compared to other Y } \\
\text { products brands is very good }\end{array}$ \\
\hline & The quality of the $\mathrm{X}$ brand products fully satisfies my needs \\
\hline \multirow{2}{*}{$\begin{array}{l}\text { Brand awareness } \\
\text { (Shariq, 2018; Baalbaki and Guzman, 2016; Jalilvand et } \\
\text { al., 2011; Tariq et al., 2017; Akhtar et al., 2016; } \\
\text { Noorlitaria et al., 2020) }\end{array}$} & When I think of Y products, I think of the $\mathrm{X}$ brand first \\
\hline & The $\mathrm{X}$ brand is very well known to me \\
\hline \multirow{4}{*}{$\begin{array}{l}\text { Brand image } \\
\text { (Zhang, 2015; Baalbaki and Guzman, 2016; Graeff, } \\
\text { 1997) }\end{array}$} & The $\mathrm{X}$ brand always makes a good impression to me \\
\hline & In my opinion, the image of the $X$ brand in society is positive \\
\hline & $\begin{array}{l}\text { The image of the } \mathrm{X} \text { brand is better compared to other } \mathrm{Y} \\
\text { products brands }\end{array}$ \\
\hline & $\mathrm{X}$ brand products give me a sense of self-esteem \\
\hline \multirow{3}{*}{$\begin{array}{l}\text { Brand trust } \\
\text { (Shariq, 2018; Ballester, 2002; Lyubenova, 2019; } \\
\text { Ballester, Munuera-Alem, 2005) }\end{array}$} & I trust the $\mathrm{X}$ brand \\
\hline & The $\mathrm{X}$ brand is sincere \\
\hline & I believe in the $\mathrm{X}$ brand \\
\hline \multirow{2}{*}{$\begin{array}{l}\text { Purchase intentions } \\
\text { (Jalilvand et al., 2011; Cobb-Walgren et al., 1995; Chang } \\
\text { and Liu, 2009; Moradi and Zarei, 2011) }\end{array}$} & I am going to buy $\mathrm{X}$ brand products \\
\hline & I will buy $\mathrm{X}$ brand products \\
\hline
\end{tabular}

The evaluation of all investigated statements in the questionnaire was performed using 7-point Likert scale. Based on the evaluations reported by respondents, regression analysis (one variable value prediction by another variable value) was made to evaluate the dimensions of brand equity and their impact on purchase intentions buying food products in Lithuania.

The demographic part of the questionnaire consists of three questions related to the demographic characteristics of the respondents: gender, age, and average income per person per month.

Data sampling. The study population was selected proportionally to reflect all 10 Lithuanian counties. 300 questionnaires were prepared and distributed using convenience sampling, 251 were returned (response rate $84 \%$ ); 227 of them were considered suitable for further analysis.

Characteristics of respondents. The respondents' demographic data is presented in Table 2.

Table 2. The Respondents' Demographic Data, \%

\begin{tabular}{|l|l|l|l|l|l|}
\hline Gender & Age & \multicolumn{3}{l|}{ Average income per person per month } \\
\hline Men & 124 & $18-24$ & 132 & $<200$ eur & 17 \\
\hline Women & 103 & $25-29$ & 44 & $200-400$ eur & 34 \\
\hline & & $30-34$ & 21 & $401-600$ eur & 61 \\
\hline & & $35-39$ & 16 & $601-800$ eur & 43 \\
\hline & & $40-44$ & 7 & $801-1000$ eur & 33 \\
\hline & & $45-49$ & 2 & $1001-1200$ eur & 17 \\
\hline
\end{tabular}

*Organization of the research. The research was provided in Lithuania in March of 2021 


\section{Research results}

To process survey data using the linear regression method, verification whether there is a linear dependency between the dimensions of brand equity, which have impact on purchase intentions, is appropriate. Purchase intentions were selected as dependent variable, and dimensions of brand equity (perceived quality, brand awareness, brand image and brand trust) were chosen as independent variables. The appropriateness of applying the linear regression method was assessed by considering the assumptions of linear regression and verifying whether they have not been violated. When the dimensions of brand equity were chosen as independent variables, the coefficients of determination (R) squared in simple linear regression were the same as squared Pearson's correlation coefficient. The squared determination coefficient was equal to 0.729 , and according to the requirements for the regression model, when the squared determination coefficient is greater than or equal to 0.25 , the regression model is considered appropriate. The appropriateness of regression model is also determined by $p$ value (when $p$ value is below the level of significance (coefficient of determination) then it can be stated that the theoretical model and observations may be claimed to be matching). In this case, when brand equity dimensions were chosen as independent variables, $\mathrm{p}$ values in the ANOVA table were equal to 0.

Applying linear regression to reach the aim of the research, the following independent variables influencing the dependent variable were included into the regression model: perceived quality, brand awareness, brand image and brand trust.

To assess the influence of independent variables (perceived quality, brand awareness, brand image and brand trust) on the value of the dependent variable (purchase intention), the regression analysis calculated the adjusted coefficient of determination. Based on the statistical estimates of the brand equity's dimensions, the resulting adjusted coefficient of determination is quite high - 0.724. The higher the value of the adjusted coefficient of determination, the better the dependent variable (purchase intentions) in the regression model is described by the independent variables. Such value of the above-mentioned coefficient allows to state that the combined influence of all analysed independent variables (perceived quality, brand awareness, brand image and brand trust) on purchasing intentions is significant.

The analysis of the brand equity dimensions showed that not every researched dimension was statistically significant; their influence on purchase intentions was not the same. Regression indicators of dimensions of brand equity, i.e., standardized coefficients describing each factor (B), and $\mathrm{p}$ value which is dependent on the chosen significance level $\alpha=0.05$ show that one of the brand equity dimensions, i.e., brand awareness, was statistically insignificant. Based on standardized coefficient (B), brand image, perceived quality and brand trust demonstrated the greatest impact on purchase intentions. Coefficients of dimensions of brand equity and their impact on purchase intentions are listed in the Table 3. 
Table 3. Brand Equity Dimensions, Having Impact on Purchase Intensions

\begin{tabular}{|c|c|c|}
\hline \multicolumn{3}{|c|}{ Brand equity dimensions } \\
\hline & Standardized Coefficients B & Sig. \\
\hline Perceived quality & 0,317 & 000 \\
\hline Brand awareness & 0,41 &, 583 \\
\hline Brand image & 0,369 &, 000 \\
\hline Brand trust & 0,187 &, 011 \\
\hline
\end{tabular}

Analysis of regression analysis, obtained by examining aspects of brand equity dimensions, revealed several results.

First, the adjusted coefficient of determination describing the impact of brand equity have high significance (0.724). Thus, brand equity strongly influences brand preference and purchase intentions directly and finally influence consumers' brand choice.

Secondly, brand image as one of the dimensions of brand equity, demonstrated the greatest impact on purchase intentions (standardized Coefficients B $-0,369$ ). Performed research about brand equity dimensions impact on purchase intentions buying food products in Lithuania revealed the same results as stated by Zhang (2015) in literature review and confirm the insights - when buying food products, the great importance of positive feelings, associations with the brand, functional and psychological attributes is noticed. Buying food products is often seen as an act of habit, but the importance of brand image to consumers reveals that even the choice of food product is strongly influenced by the brand image.

Thirdly, perceived quality, as a second most significant dimension of brand equity (standardized Coefficients B $-0,317$ ), reveals the importance of consumers' requirements. According to research results it can be stated that food products' perceived quality directly influences to purchase intention. The customers consider perceived quality as a more specific concept based on product and service features, and in the context of overall brand equity, perceived quality can deeply influence consumer's choices.
Fourthly, brand trust, little examined in other research, also demonstrated a significant influence on purchase intentions (standardized Coefficients B - 0,187). According to the research results, it can be concluded that this dimension of brand equity emphasizes the importance of repetitive buying behaviour, when not only all expectations about the brand is fulfilled, but consumer is confident that this will continue to be the case. Buying food products, consumers pay particular attention to aspects of trust and confidence, and if they feel secure with the brand, their purchase intensions tend to increase.

\section{Conclusions}

Brand equity concept, as a concern of modern organizations, can be analysed from different perspectives, depending on their classification: financial, consumer-based, or mixed perspectives; cognitive psychology, information economics, or financial perspective; employee-based perspective. Chosen consumerbased approach defines brand equity as an added value generated by the brand.

Brand equity concept is understood through a wide range of its dimensions. Perceived quality, brand awareness, brand image, and brand trust are the dimensions analysed in the article. Perceived quality can play a major role determining consumer's choice, provides customers a reason to buy, convinces customers to buy the brand, enhance brand loyalty. Perceived quality is directly linked with purchase intentions. Brand awareness is the ability of a brand to get recognized before customers make purchase 
Management Theory and Studies for Rural Business and Infrastructure Development

eISSN 2345-0355. 2021. Vol. 43. No. 3: 373-382

Article DOI: https://doi.org/10.15544/mts.2021.34

intentions. It plays an important role in consumer decision making process because of learning, consideration, and choice advantages. Brand image influence is one of the most popular reasons why a consumer makes purchase decision and is more important rather than physical characteristics of brand. Brand trust can be understood as a predictor of repetitive purchase behaviour and a moderator of the impact of brand loyalty.

Based on literature review, despite both brand preferences and purchase intentions are consequences of brand equity, brand equity dimensions can influence purchase intentions directly or through brand preferences first.

Based on the research results, brand awareness, as the dimension of brand equity, doesn't have significant impact on purchase intentions buying food products in Lithuania. That means, customers'decision making buying food products are weakly influenced by brand awareness. Other dimensions - brand image, perceived quality and brand trust are deeply associated with purchase intentions buying food products in Lithuania. Following their significance and strength of their impact on purchase intentions, brand equity dimensions are listed in such order: brand image, perceived quality, brand trust. Organizations that develop food brands and seek to encourage desired consumer behaviour should focus on building brand image, identifying and ensuring the quality of products desired by consumers and increasing brand confidence.

\section{References}

Aaker, D. A. (1991). Managing brand equity. Free Press: New York, NY.

Aaker, D. A. (1996). Building Strong Brands: Building, Measuring, and Managing Brand Equity. Free Press.

Akhtar, N., Ain, Q., Siddiqi, U.I., Ashraf, A. and Latif, M. (2016). Impact of brand equity on consumer purchase decision in L'Oreal skincare products // International Review of Management and Business Research, Vol. 5 No. 3, pp. 808816.

Alhaddad, A. (2015). Perceived Quality, Brand Image and Brand Trust as Determinants of Brand Loyalty // Journal of Research in Business and Management. Volume 3 Issue 4(2015) pp: 01-08 ISSN (Online): 2347-3002

Anselmsson, J., Bondesson, N.V., and Johansson, U. (2014). Brand image and customers' willingness to pay a price premium for food brands // Journal of Product \& Brand Management. 23(2).

Atilgan, E., Aksoy S. and Akinci S., (2005). Determinants of the brand equity: A verification approach in the beverage industry in Turkey // Marketing Intelligence \& Planning. 23(3): 237-248.

Baalbaki, S., Guzman, F. (2016). Consumer-based brand equity. Chapter in book: The Routledge Companion to Contemporary Brand Management. Publisher: Routledge Minho.

Ballester, E. D. (2002). Development and Validation of a Brand Trust Scale // EMAC Proceedings. Universidade do

Boo, J., Busser S. and Baloglu S. (2009). A model of customer-based brand equity and its application to multiple destinations // Tourism Management. 30(2): 219-231.

Buil, I., Martínez, E. and de Chernatony, L. (2013). The influence of brand equity on consumer responses // Journal of Consumer Marketing. 30(1), 62 - 74.

Chang, H. H., Liu, Y. M. (2009). The Impact of Brand Equity on Brand Preference and Purchase Intention in the Service Industries // The Service Industries Journal. Vol. 29, No. 12, pp. 1687-1706.

Chen. Ch., Chang, Y. (2007). Airline brand equity, brand preference, and purchase intentions - The moderating effects of switching costs // Journal of Air Transport Management. 14(1), pp. 40-42

Civelek, M.E., Ertemelb, A.V. (2019). The role of brand equity and perceived value for stimulating purchase intention in B2C e-commerce web sites // Business and Economics Research Journal. Vol. 10 No. 1, pp. 233-243.

Delgado-Ballester, E., Munuera-Alema'n J. L. (2005). Does Brand Trust Matter to Brand Equity? // Journal of Product and Brand Management. 14(2/3), 187-196. 
Deloitte (2021). Global Powers $\quad$ of 2021. https://www2.deloitte.com/content/dam/Deloitte/at/Documents/consumer-business/at-global-powers-retailing-2021.pdf [2021 07 15]

Dissabandara, R. (2020). Impact of brand equity and loyalty on consumer behaviour for clothing industry in Sri Lanka // International Journal of Current Research. Vol. 11 No. 5, pp. 3782-3787.

Farquhar, P. H. (1989). Managing brand equity // Marketing Research. 1 (3): 24-33.

Graeff, T. R. (1997). Consumption situations and the effects of brand image on consumers' brand evaluations // Psychology \& Marketing. 14(1), 49-70

Hazée, S., Van Vaerenbergh, Y. and Armirotto, V. (2017). Co-creating service recovery after service failure: the role of Brand equity // Journal of Business Research. Vol. 74, pp. 101-109.

Jalilvand, M. R., Samiei, N., Mahdavinia, S. H. (2011). The effect of brand equity components on purchase intention: an application of Aaker's model in the automobile industry // International Business and Management. Vol 2, No. 2.

Keller, K., L. (1996). Integrated Marketing Communications and Brand Equity, in Integrated Marketing Communications, eds. Jeri Moore and Esther Thorson, Mahwah, NJ: Lawrence Erlbaum Associates, 103-132.

King, C., Grace, D. (2009). Employee based brand equity: a third perspective // Services Marketing Quarterly. 30 (2): $122-47$

Leone, R.P., Rao, V.R., Keller, K.L., Luo, A.M., McAlister, L. and Srivastava, R. (2006). Linking brand equity to customer equity // Journal of Service Research. 9(2): 125-138.

Luybenova, V. (2019). Brand trust as a source of brand equity. https://www.researchgate.net/publication/342380920_BRAND_TRUST_AS_A_SOURCE_OF_BRAND_EQUITY [2021 07 15]

Moradi, H., Zarei, A. (2011). The Impact of Brand Equity on Purchase Intention and Brand Preference - the Moderating Effects of Country-of-Origin Image // Australian Journal of Basic and Applied Sciences. Vol. 5(3). P. 539-545.

Noorlitaria, G., Pangestue, F.R., Fitriansyah, S.U. and Mahsvar, S. (2020). How does brand awareness affect purchase intention in medication by perceived quality and brand loyalty // Journal of Critical Reviews. Vol. 7 No. 2, pp. 103-109.

Pappu, R., Quester, P.G., Cooksey, R.W. (2005). Consumer-based brand equity: improving the measurement empirical evidence // Journal of Product \& Brand Management. 14(3): 143-154.

Perera, K., Wijisekera, K., Priyadarshani, B., Koodippili, L. and Jayssuriya, N.A. (2019). The study of brand equity and purchase intention of shampoo market in Sri Lanka // Global Journal of Management and Business Research: EMarketing. Vol. 19 No. 4, pp. 24-28.

Seric, M., Gil-Saura, I. (2020). Understanding brand equity in hotel firms. What is the role of brand equity and satisfaction? // International Journal of Contemporary Hospitality Management. Vol. 31 No. 9, pp. 3526-3546.

Severi, E., Ling, K. Ch. (2013). The Mediating Effects of Brand Association, Brand Loyalty, Brand Image and Perceived Quality on Brand Equity // Asian Social Science. Vol 9. No 3.

Shariq, M. (2018). Brand equity dimensions - a literature review // International Research Journal of Management and Commerce. Vol. 5. Issue 3. P. 312-330.

Kumar, Sh. R., Dash, S., Purwar, P.C. (2013). The nature and antecedents of brand equity and its dimensions // Marketing Intelligence \& Planning, 31(2), $141-159$.

Tariq, M., Abbas, T., Abrar, M. and Iqbal, A. (2017). EWOM and Brand awareness impact on consumer purchase intention: mediating role of brand image // Pakistan Administrative Review. Vol. 1 No. 1, pp. 84-102.

Vukasovic, T. (2016). A conceptual framework for understanding consumer-based brand equity. Proceeding on the joint international conference "Managing innovation and diversity in knowledge society through turbulent times". May 2527. Pp. 991-997.

Zhang, Y. (2015). The Impact of Brand Image on Consumer Behaviour: A Literature Review // Open Journal of Business and Management. 58-62. http://dx.doi.org/10.4236/ojbm.2015 .31006 